\section{Placer Gold in SW-Bulgaria: Past and Present}

\author{
Hans-Gert Bachmann \\ Wildaustrasse 5, D-63457 Hanau, Germany \\ E-mail: hgb.hanau@t-online.de
}

\section{Zdravko Tsintsov}

Central Laboratory of Mineralogy and Crystallography, Bulgarian Academy of Sciences,

bl. 107, Acad. G. Bonchev Str., 1113 Sofia, Bulgaria

E-mail: ztsintsov@mail.bg

Gold mining and beneficiation in SW-Bulgaria dates back to antiquity. Investigations of the area have made unique discoveries. Small archaeological gold artifacts (ringlets, wire etc.) of yet unknown age, as well as gold prills and beads from melting, have been found together with native gold. Occasionally, platinumgroup minerals (PGM), e.g. osmium-iridium-rutheniumalloys, are associated with gold and other heavy minerals in placers. The beneficiation of precious metals (panning by gravity separation) also included underground mining of auriferous conglomerates.

\section{Early and Greek History}

The use of gold in Bulgaria goes back to prehistory. The Chalcolithic necropolis of Varna near the Black Sea has revealed a wealth of artifacts made by skilful artisans (1). Further to the West, at Kotan in Montenegro, golden ringlets from an early 3rd millennium burial tumulus have been investigated (2). The source of gold for the manufacturing of these objects is as yet unknown. In the 2nd millennium BC, Bulgaria was the homeland of the Thrakians. They were later (around the 5th century BC) replaced by Greeks (predominantly in the region near the Black Sea) and Macedonians. Classical authors have frequently referred to the wealth of Thrakia. The country must have had a significant potential not only of gold, but also of silver and copper. The tribe most experienced in mining and metal working were the Bessi. These privileged miners even had the permission to wear swords (3). The river Struma (Strymon), for a long time the border between Thrakia and Macedonia, was renowned for its placer gold. It was on the banks of this river near Kjustendil, as well as in other places, that gold was retrieved. The primary rock formations, which supplied these placers are as yet unknown (4).

\section{Roman Province}

Under Roman rule, northern Bulgaria belonged to the province of Moesia inferior, the south became Thracia. It was at this time still inhabited by the tribe of the Bessi. The important settlement of Pautalia (= Kjustendil) was in the land of the Dantheletei (5). Apparently, the Dantheletei were a branch of the aforementioned Bessi. They settled here not only because of the vicinity to a spring, but perhaps also because of nearby ore deposits.

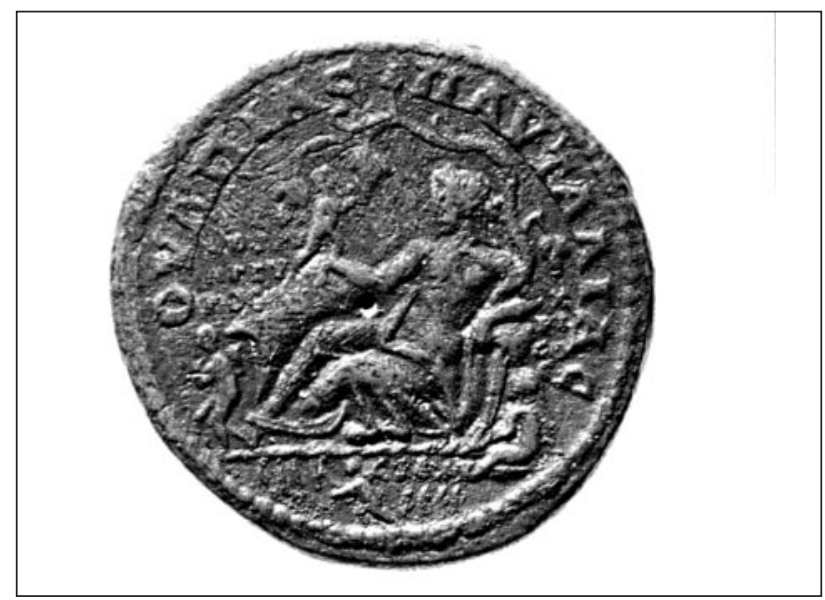

\section{Figure 1}

Roman provincial coin from Pautalia (Kjustendil), reverse, with representations referring to mining (for details cf. text), weight 18.74 grams, scale $2: 1$ (copyright: Staatliche Museen zu Berlin, Münzkabinett) 
Further evidence to ancient mining activities are local Roman bronze coins. The specimen illustrated (fig.1) was minted under Caracalla (211-217 AD). It resembles similar pieces issued by his mother Julia Domna († 217 AD) and his father Septimius Severus (193-211 AD). They were struck in Philippopolis and Pautalia. On the obverse of the coin shown, a nymph, personification of the rivers Maritza (Hebros) and Struma (Strymon), rests her right hand on a mountain ridge. Her left arm, supported by an urn, grasps a vine with grapes and leaves. The Greek inscription unequivocally identifies Pautalia as the minting city: OV $\Lambda$ ПIAC ПIAVTA $\Lambda$ IAC. On a mountain ridge a genius or naked boy picks grapes: BOTPY. Close to the entrance of a gallery another genius carries a bag of silver or silver ore: АРГYPOC. Close to water flowing out of an urn, a third genius pans gold: XPYCOC. In the lower section of the coin's effigies a fourth genius gathers bundles of grain: CTAXY in a field. Thus, the four riches of the country: gold, silver, cereals and wine are symbolized (6).

Presumably, the mineral wealth of Thracia was a major incentive for its occupation by the Romans. In addition to surface extraction of gold from placers, auriferous sands and gravels were mined from hard Paleogene conglomerates in galleries underneath river beds. In allusion to this technique, the underground workings were called cuniculi more Bessorum ( = galleries in the fashion of the Bessi), referring to the expertise of this local tribe.

\section{From Medieval to Modern Times}

The decline of the Roman Empire led to a decrease of gold extraction in the region of Pautalia. It was partly revived in the 13th century AD by Saxon miners, known to the locals as "utmanı". The name has as its origin in the German word "Hüttenmann" = worker in a smelter. The village of Sasa (now in Macedonia) derives its name from the Saxon miners. After these foreigners had left the region, gold mining virtually came to a stand still and only had a revival in the 20th century.

Despite its long history, very little is actually known about the placer deposits in the Kjustendil region. One reason for the lack of information is the common opinion of geologists that gold placers in the territory of present Bulgaria have all been exploited and are exhausted. Indeed, it is hardly possible to-day to discover a placer deposit which has not been worked at one time or another. Remains of ancient gold mining from the exploitation of secondary deposits are still visible. Galleries from underground mining of hard Paleogene conglomerates, open pits, relics of machinery for hoisting and pumping, dumps, tools for panning and other equipment for retrieval of placer gold, even vessels filled with gold grains (7) are proof that precious metals have played a
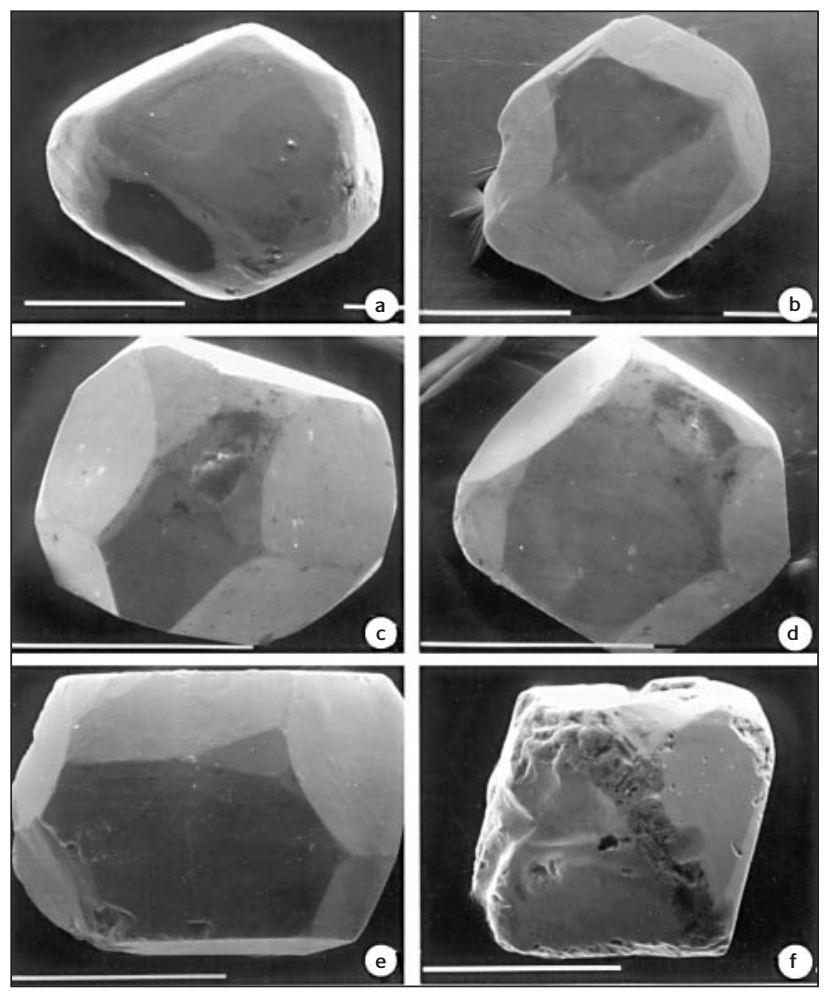

Figure 2

SEM micrographs of individual sperrylite crystals from Struma river region (Kjustendil "graben"); scale bars = 0.1 millimetre
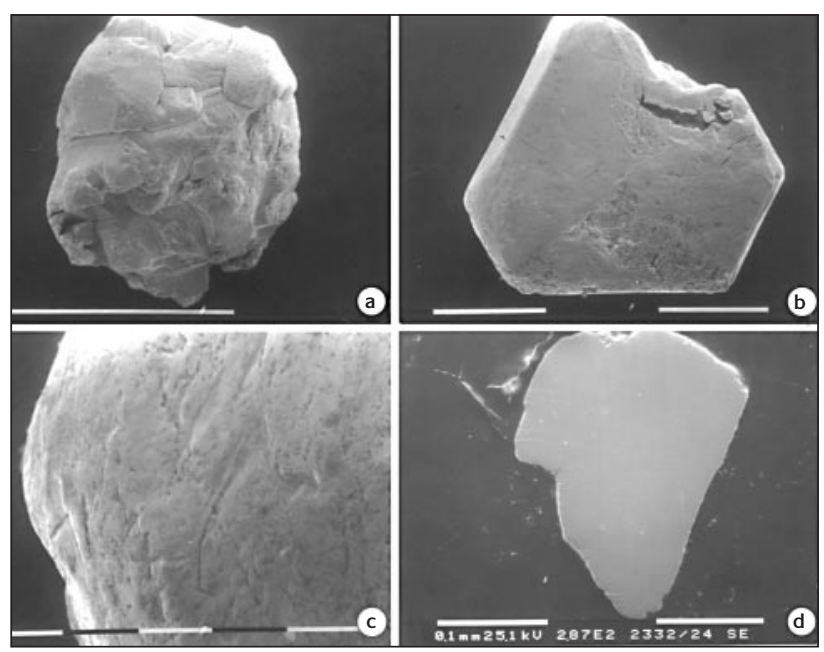

Figure 3

SEM micrographs of Os-Ir-Ru- alloy grains from Struma river region (Kjustendil "graben"), original surfaces (a - c), polishes section (d); scale bars $=0.1$ millimetre $(a, b, d)$ and 0.01 millimetre (c)

significant role in the lives of local inhabitants. Recent investigations of placer gold deposits by geologists, mining engineers and archaeologists have revealed some of the questions and problems involved in understanding ancient activities. Dating the various remains is as much a task for the investigators as the interpretation of the few written sources. 
Table 1

Electron microprobe analyses (in weight percent) of Os-Ir-Ru alloys from the Kjustendil region

\begin{tabular}{|c|c|c|c|c|c|c|c|c|c|}
\hline & $132 / 1$ & $132 / 2$ & $132 / 3$ & $132 / 4$ & $132 / 5$ & $130 / 2$ & $105 / 1$ & $105 / 2$ & $105 / 4$ \\
\hline Ru & 5.50 & 46.81 & 30.25 & 1.90 & 38.09 & 8.34 & 11.83 & 2.88 & 5.31 \\
\hline Rh & nd & nd & nd & nd & nd & nd & nd & nd & 3.65 \\
\hline Os & 60.12 & 45.01 & 35.34 & 31.78 & 30.87 & 28.99 & 47.19 & 35.32 & 27.82 \\
\hline Ir & 33.08 & 8.65 & 33.07 & 64.10 & 28.25 & 55.01 & 42.08 & 50.42 & 55.58 \\
\hline Pt & nd & nd & nd & nd & 3.43 & 7.08 & nd & 9.65 & 6.78 \\
\hline $\mathrm{Fe}$ & nd & nd & nd & nd & nd & nd & 0.23 & 0.08 & 0.58 \\
\hline $\mathrm{Ni}$ & nd & nd & nd & nd & nd & nd & 0.21 & 0.04 & 0.01 \\
\hline Total & 98.70 & 100.47 & 98.66 & 97.78 & 100.64 & 99.42 & 101.54 & 98.39 & 99.73 \\
\hline
\end{tabular}

Though the deposits in the Kjustendil region had been worked extensively in the past, they are apparently not yet completely exhausted. Some of them have again become a focus of attention. Exploration and exploitation are conducted by several enterprises; five of them using mechanical equipment on a small scale to work placers of the Struma and Dragovishtitsa. The renewed economical interest in this area has also fostered scientific research.

\section{Associated Platinum-Group Minerals (PGM)}

It was discovered, that occasionally the gold placers also contain platinum group minerals (PGM). This explains why in the past reference had been made to so-called "white gold".

Grains and particles of PGMs (minerals and alloys) of varying composition include: sperrylite, PtAsz, (fig.2) Pt-Fe-alloy, Os-IrRu-alloys (fig.3) and mertieite II, $\mathrm{Pd}_{8}(\mathrm{Sb}, \mathrm{As})_{3}$ (8). Analytical data of some characteristic Os-Ir-Ru-alloys from the Struma river region (not identical with those illustrated) are summarized in table 1. Though PGMs are frequently encountered in placer gold deposits worldwide (9), the discovery of PGMs in Bulgarian placers is fairly recent. Alloys of Os-Ir-Ru, extremely hard and resistant to abrasion, are of special interest. Apart from these three platinum metals, the associated PGMs may contain Pt and $\mathrm{Rh}$, also sometimes $\mathrm{Fe}$ and $\mathrm{Ni}$ (the latter probably as autonomous minerals or intermetallic compounds); cf. fig.3 and table 1. A detailed description of PGMs in SW-Bulgarian placers has been published elsewhere (10).

\section{Artifacts in Placer Gold}

(For a detailed map of the region with place names cf. fig.4)

The most striking recent discoveries, however, are finds of ancient gold artifacts in Bulgarian placers (figs. 5, 6a,b,c and 7). During the process of erosion, early anthropogenic strata or horizons (containing burials, workshops, hidden treasures etc.) were subjected to exposure and subsequent fluvial transport. The objects (usually very small) thus released from their surroundings were included among the heavy minerals and metals in the placer sediments. As yet, we have no indication neither of the age of these anthropogenic objects nor of their cultural context. The Museum of Natural History in Sofia has these rare and precious finds in custody.

Extensive gold mining was undoubtedly practiced from antiquity to relatively modern times. Thus, the search for gold processing workshops is a desideratum, albeit these installations have vanished long ago. In the middle of the 20th century, locals living near the place called "Porta", have found remains of foundations from a ancient building, probably a former workshop, associated with ceramic sherds and slags.

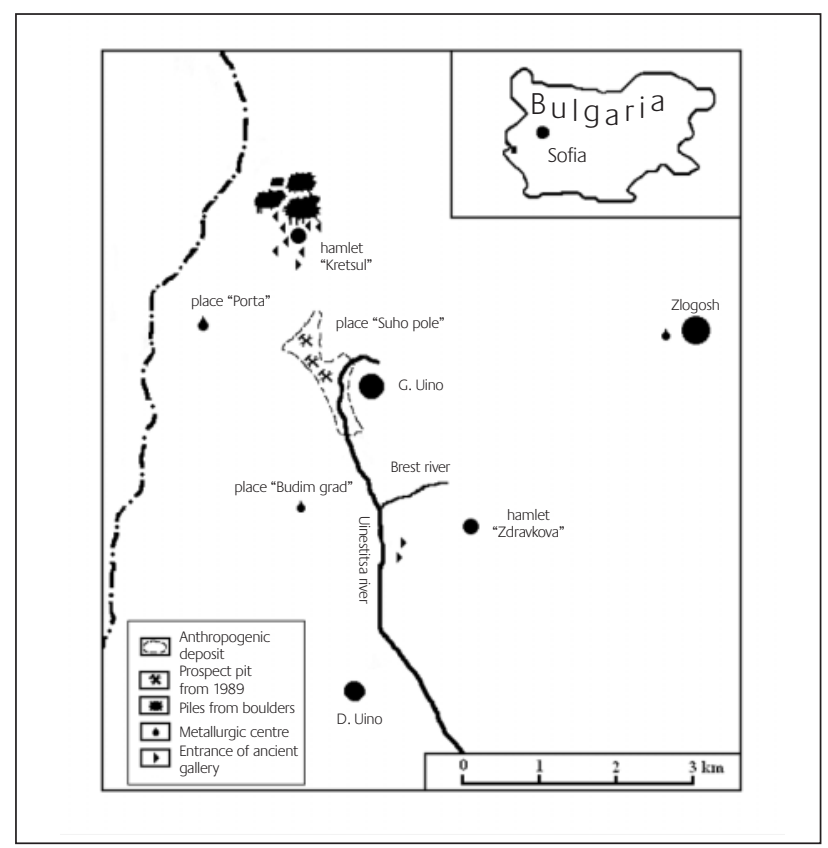

Figure 4

Map of SW-Bulgaria with place names mentioned in the text 


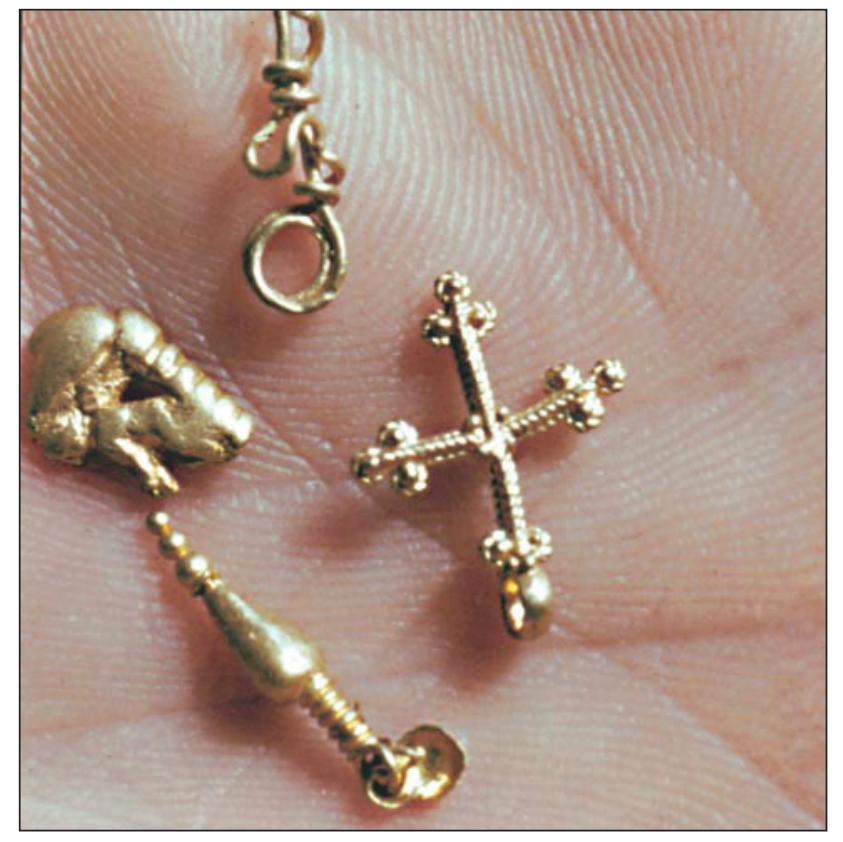

Figure 5

Small gold artifacts from Western-Bulgarian placers on the palm of a hand; sizes ca. 1 to 4 millimetres

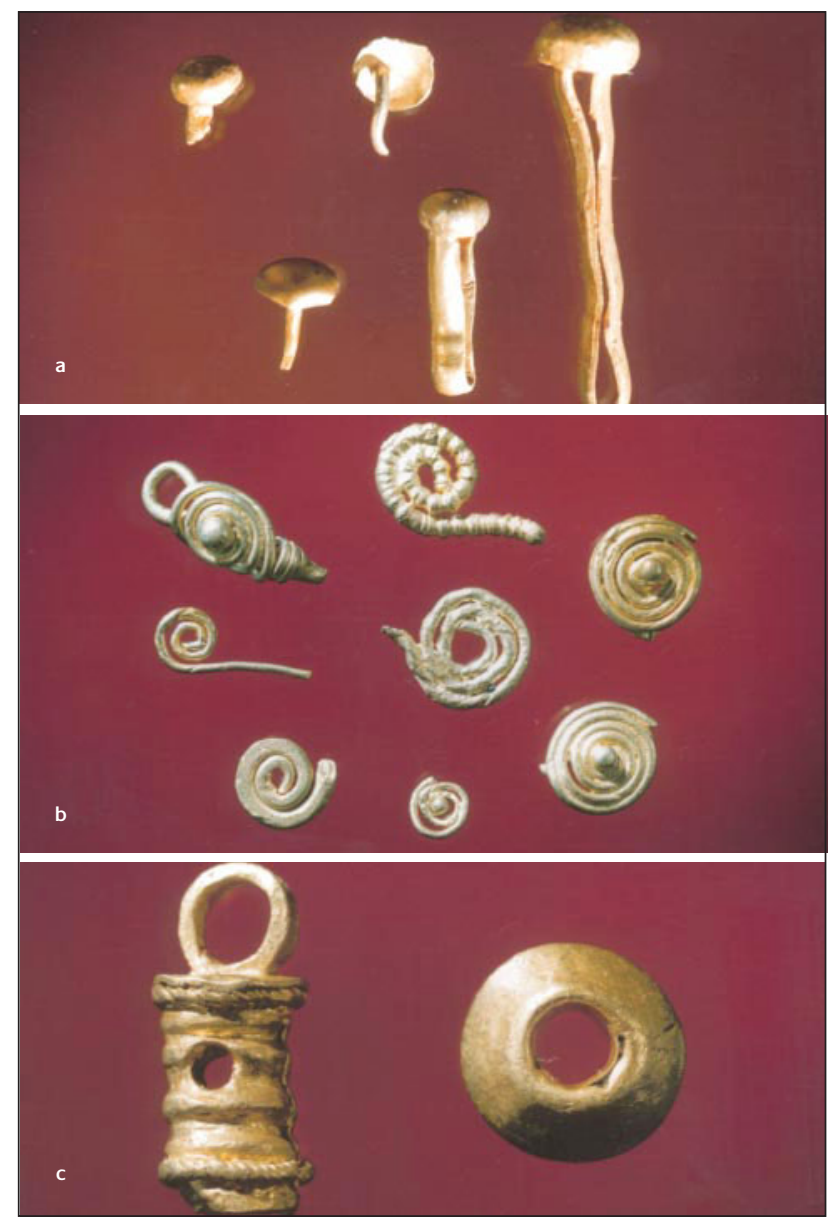

\section{Figure 6}

a, b, c: Gold rivets (a), coils (b) and pendant + ring (c) from SWBulgarian placers; sizes between 1 to 3 millimetres
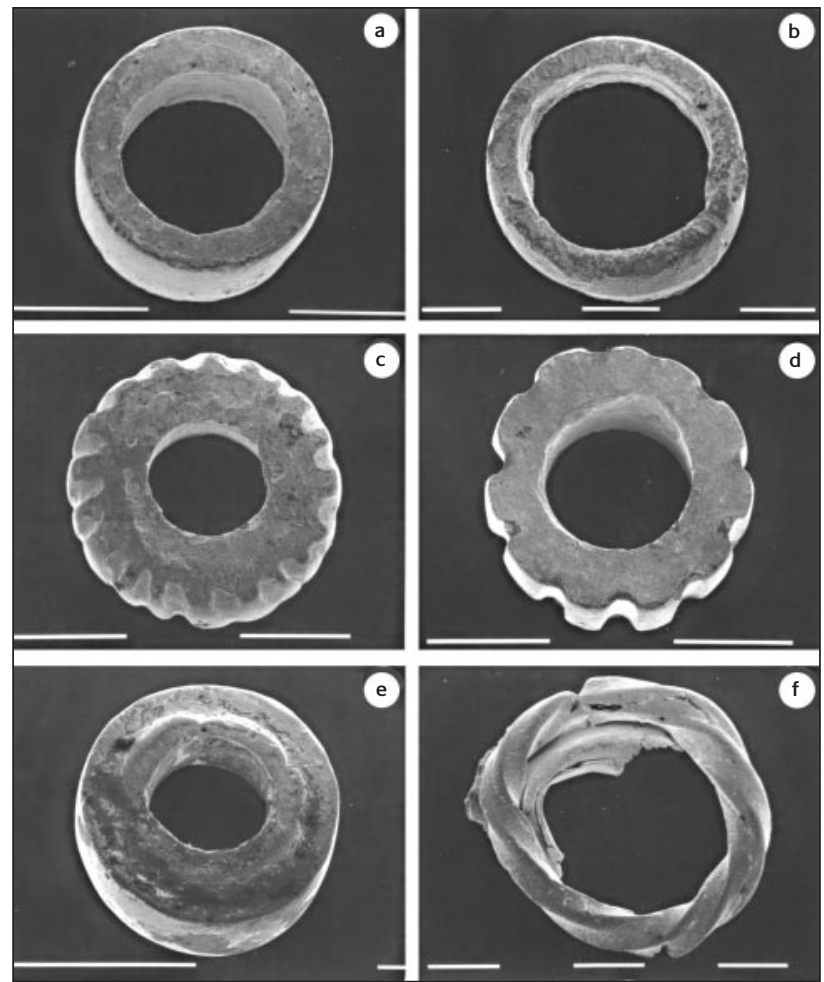

Figure 7

SEM photographs of gold ringlets from the Kjustendil region: (a) and (b) from G. Uino, (c) and (e) from Katriste, (d) and (f) from Tshetirtsi; original surfaces; scale bars $=1$ millimeter

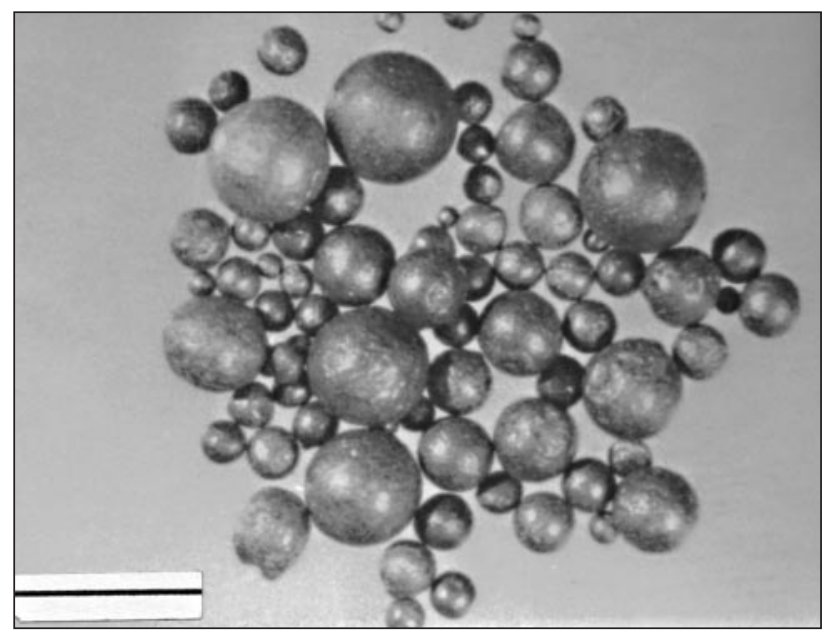

Figure 8

Micrograph of artificial gold globules from Struma river region; scale bar $=5$ millimetres

Indirect evidence of former gold treatment is to be found in the region of Gorno Uino village. Here, gold objects have been retrieved in considerable quantity, especially, a large number of gold globules or prills (figs. 8 and 9). They were found in alluvial sediments of the Uinestitsa river and its tributaries. The waters of "Porta" and "Budim grad" drain into the Uinestitsa. There used to be a direct connection between 


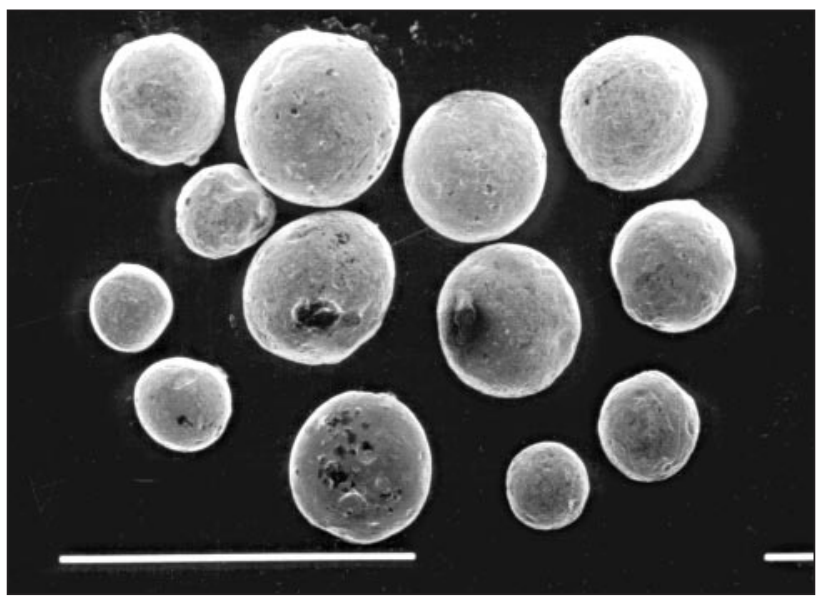

Figure 9

SEM micrograph of artificial gold globules from Struma river region; scale bar $=1$ millimetre

mining and processing. The prills and tiny beads of gold indicate that molten metal was quenched by pouring it into water. Many such artifacts have been found in the bed of the river Struma and its tributaries in the Kjustendil area. They are small in size (below $4 \mathrm{~mm}$ in diameter) and deformed due to fluvial transport. Several thousands of prills have been found thus far, indicating former large-scale production. But how did they get into the river?. Were gold objects dumped into the rivers as sacrifice? Was there a natural catastrophe or an enemy attack, driving the workshop people out of their homes and working places? The stores and their contents apparently were destroyed and a large number of objects lost and sunk into the rivers. Or the waterways had changed their courses and flooded the habitation and working sites of former inhabitants? We have as yet no plausible convincing answer. Tiny gold artifacts are not restricted to placers in SWBulgaria. Similar objects have also been found in auriferous gravel and sand beds in NW-Bulgaria (11). Here too, their origin is enigmatic.

\section{New Use for Tailings}

The main intention of prospecting (in addition to research) is the study of sediments as a potential source of building materials (sands, gravels etc.). Main attention was, therefore, drawn to the alluvial sediments in the Pliocene "graben" of Kjustendil and the region near the village of Gorno Uino, equally famous for its former placer gold resources.

The intention of this work is the presentation of new data for the Gorno Uino region, such as:

i) The distribution and characterization of gold placer deposits.

ii) The localization and amount of tailings (waste heaps) left behind from gold recovery operations.

iii) The documentation of mining activities in the past, mainly galleries.

iv) The localization of ancient manufacturing center(s) for gold artifacts.

v) Additional observations on the nature of placer gold and the distribution of anthropogenic objects (artifacts) in placers of the Kjustendil region.

The survey of the area and its placers, was carried out with equipment for gravity concentration of placer gold in streams with moderate currents (stationary as well as mobile units). The equipment was able to extract also flaky, "floating gold" particles $(<200 \mu \mathrm{m})$. The stationary concentrators with their scavenging facilities could treat sands and gravels near Tshetirtsi village. The mobile units, a simple version of the stationary ones, were easily transported to different working positions. The method of sampling chosen (especially with the stationary units) permitted the treatment of large volumes of material (up to $1000 \mathrm{~m}^{3}$ ). With the aid of manually operated equipment, the concentrates from large-scale operations were significantly upgraded. Sediments with placer gold could reach $55-60 \%$ of the total amount of the material treated. The upgraded, rich concentrates were further divided into fractions with laboratory sieves to permit optical inspection by binoculars.

The sediments in the region around Gorno Uino can be grouped into the following categories:

i) Quaternary low-grade auriferous alluvial deposits, present in river valleys (type "Uinestitsa river"). Their gold content is of the order of 15 to $420 \mathrm{mg} / \mathrm{m}^{3}$.

ii) Coarse, unclassified, loosely cemented conglomerates of Neogene or Paleogene age. Large amounts of these had been processed in the past. Remnants of mining activities and left-behind boulders (type "Kretsul") are abundant. Placer gold content may reach 0.30 to $1.85 \mathrm{~g} / \mathrm{m}^{3}$.

iii) In hills of sand left behind after washing and panning (type "Suho pole"), a residual gold content of 20 to 65 $\mathrm{mg} / \mathrm{m}^{3}$ is still present. The name is derived from the most prominent locality of these waste heaps.

\section{Former Gold Extraction Methods}

With regard to the mode of gold extraction by the ancients, two methods seem to have been employed: Surface recovery from loose material and underground mining of cemented conglomerates. The thickness of the auriferous formation differs from some tens of centimeters to several meters. In some places even a height of $20 \mathrm{~m}$ can be exceeded (type "Suho pole"). The heavy mineral composition varies. It includes magnetite, ilmenite, almandine, chromian spinel, gold, zircon, monazite, xenotime, rutile, pyrite, galena, cinnabar etc. Especially, the nature of the placer gold from 
Gorno Uino village has been studied. Recent work has discovered high contents of placer gold at the base of Paleogene conglomerates (type "Kretsul") in the region of Zdravkova hamlet and nearby Tsurvilitsa. In these localities, irregular gold concentrations may go up to $12.45 \mathrm{~g} / \mathrm{m}^{3}$. Even nuggets of $15 \mathrm{~g}$ in weight have been found. Accidentally, two entrances to ancient galleries (now partly caved-in) were discovered in 1985. Ancient entrances to mines in the conglomerate beds near Kretsul are known to the local inhabitants as "fox-holes". In the past, they were used for cold storage. In the region of Zdravkova, galleries were driven into the base of the conglomerate layers to follow horizons rich in gold. They are up to 12 meters long, 1.30 to 1.40 meter high and 2.40 meter wide. Their oval profile has been preserved, even without timbering. Deposits of the Kretsul type are also found near the hamlet of the same name. They are buried under accumulations of boulders, but several sectors are still accessible. The smallest of these covers an area of 500 to $600 \mathrm{~m}$ _ and the largest one of about $2000 \mathrm{~m}^{2}$.

The waste heaps (tailings) are in the topographically lower part of the terrain. The ancient miners removed the large boulders of the Paleogene conglomerate prior to processing the remaining sand for gold. The boulders were thrown into cavities and pits formed by removal of the Paleogene conglomerates. It is difficult to estimate the volume of these tailings, because nowadays they are mostly covered with a topsoil of clays and sands and overgrown with trees and shrubs. The removed boulders are generally round and of sizes between 20 to 55 centimeters in diameter. They consist of granite, gneiss, schist, trachyte, rhyolite etc. Their sizes indicate, that they had to be removed by one or two persons. The bigger blocks were first crushed to smaller pieces. Regarding the present morphology and the sediments (type "Suho pole") left behind by early miners, the locality, where the auriferous sand had been panned can only be guessed.

The gold retrieval operations were presumably once carried out about 300 to 400 meters to the southeast of the deposits exploited. The slurry, i.e. the tailings from panning, had flown in the direction towards the "Suho pole". A large "man-made" embankment is now witness to the former activities. It consists of sand and has a volume of 8 million $\mathrm{m}^{2}$. An investigation in August 1989 had shown that a sand fraction of 0.15 to 8.00 $\mathrm{mm}$ accounts for about $65 \%$ of the sediments. The remainder being "pea stone" (8 to $20 \mathrm{~mm}$ ), plus a small amount of gravel (> $20 \mathrm{~mm}$ ). Other sediments in the Kjustendil region have a higher percentage of gravel combined with sands. The latter amounting to not more than 32 to 35\%. These deposits were sampled in three pits, up to 13.60 meters deep. Bed rock was not reached. The profile inside the pits showed the deposits to be uniform without a macroscopic difference in grain sizes, thus indicating normal sedimentation. These observations and the fact that sand is the main material, are considered to be proof that the artificial sediments are the result of gold-washing operations. More than $40 \%$ of the gold particles still in the sands, fall into the fraction 0.20 to $1.00 \mathrm{~mm}$. Their morphology is isometric, kidney-shaped or platy, actually making them quite suitable for modern gravitational separation. Obviously, in former times only Paleogene conglomerates with gold grains $>1 \mathrm{~mm}$ had been treated. Attention was apparently restricted to the coarser gold fraction and anything below that size, i.e. the finer fractions, was dismissed.

\section{Acknowledgements}

We wish to thank A. Enev (CLMC-BAS), K. Radoikov (Gorno Uino) and D. Stoyanov (Kjustendil) for their technical assistance and helpful advice on ancient gold extraction in the region of Gorno Uino village.

\section{About the Authors}

Prof Dr Hans-Cert Bachmann studied chemistry, mineralogy and geology at the University of Bonn (Germany). Until his retirement in 1993, he held senior management positions in the former German Gold-and-Silver-Refinery (DEGUSSA). He has been engaged in archaeometallurgical research since the mid-fifties of the last century and has a teaching appointment in the Department of Materials Science, Institute of Archaeology, University College, London.

Prof Dr Zdravko Tsintsov from the Central Laboratory of Mineralogy and Crystallography at the Bulgarian Academy of Sciences is working on the mineralogy of precious metals, including PGMs, from placers and host rocks (ultrabasites etc.) in Bulgaria. Since 1995 he has been teaching at the Faculty of Geology, University of Sofia.

\section{References}

1 Catalogue “Das erste Gold der Menschheit”, 2nd ed., Freiburg, 1986; also Catalogue "Varna; Le Premier Or de l'Humanité - RMN”, Paris, 1989

2 H. Primas \& C. Raub, Velika Gruda. Ein Grabhügel des 3. und 2. Jahrtausend v. Chr. In Montenegro. - Arch. Korrespondenzblatt 22, 47 - 55 (1992)

3 Several references related to subjects discussed in this article have been published in Bulgaria. However, we have refrained from quoting these, as they are in Bulgarian. Readers interested should contact the co-author Z. Tsintsov

4 H. Quiring, ,Geschichte des Goldes', Ferdinand Enke Verlag, Stuttgart, 1948.

5 L. Russeva-Slokoska, 'Pautalia. Topography, Urbanization and System of References continued on page 157 